\title{
Rat Aortic Smooth Muscle Cells in Culture Express Kallikrein, Kininogen, and Bradykininase Activity
}

\author{
Narendra B. Oza, John H. Schwartz, H. Danana Goud, and Norman G. Levinsky \\ Renal Section, Evans Memorial Department of Clinical Research and Department of Medicine, University Hospital, \\ Boston University Medical Center, Boston, Massachusetts 02118
}

\begin{abstract}
We have studied rat vascular smooth muscle (VSM) cells in culture for the presence of key elements of the glandular kallikrein-kinin system. Direct radioimmunoassay (RIA) using antiserum against rat urinary kallikrein detected a glandular kallikrein-like enzyme (GKLE) in VSM cells and in media. VSM homogenates and culture media had kininogenase activity, generating kinins from dog kininogen. About half of the GKLE was enzymatically inactive which could be activated with trypsin. Kininogenase activity was inhibited completely by aprotinin but only $20 \%$ by soybean trypsin inhibitor (SBTI). Trypsin liberated kinins from homogenates and media, demonstrating that VSM cells contain kininogen. Homogenates and media rapidly degrade bradykinin. GKLE, kininogen, and bradykininase activity were all present in VSM cells grown in defined media that contain no serum, thus eliminating any contamination or artefacts from fetal calf serum in standard culture media.

Blood vessels of the rat have been reported to contain GKLE. Our observations indicate that GKLE is synthesized by VSM cells, not deposited from plasma. Furthermore, VSM cells synthesize kininogen and bradykininase(s), the other key elements of the glandular kallikrein-kinin system. Thus it is possible that the system functions as an autocoid mechanism that regulates local vascular tone. (J. Clin. Invest. 1990. 85:597-600.) kallikrein-kinin system • kinins and blood pressure • glandular kininogenase of aorta $\bullet$ blood vessel wall kallikrein • kallikrein and vascular tone
\end{abstract}

\section{Introduction}

The glandular kallikreins (EC 3.4.21.8) are a subgroup of serine proteases that are encoded by a multigene family (1). The enzymes belong to a larger family of kininogenases, which yield hypotensive peptides, kinins, by limited proteolytic cleavage of kininogen (2). Generation of kinins is regarded as a major in vivo function of glandular kallikrein. Recent studies have suggested that these enzymes can also activate proen-

Address reprint requests to Dr. Oza, Renal Unit E428, Department of Medicine, University Hospital, Boston University Medical Center, 75 East Newton Street, Boston, MA 02118.

Received for publication 11 September 1989. and in revised form 24 October 1989.

J. Clin. Invest.

(c) The American Society for Clinical Investigation, Inc.

$0021-9738 / 90 / 02 / 0597 / 04 \$ 2.00$

Volume 85, February 1990, 597-600 zymes (3), hormones (4), and growth factors (5), and can degrade biologically active molecules such as atrial peptides (6), apolipoproteins (7), and sodium channels (8). Although glandular kallikrein can process a variety of natural substrates, the precise physiological and pathological roles of this enzyme system are not known.

Glandular kallikrein was initially identified in urine, kidney, pancreas, and salivary glands. Recent evidence indicates that this enzyme occurs in many additional organs such as skeletal muscle (9), erythrocytes (10), and the central nervous system (11). Nolly et al. (12) reported the occurrence of a glandular kallikrein-like enzyme (GKLE) ${ }^{1}$ in rat vascular tissue. In the present studies we have confirmed this finding. Synthesis by vascular tissue of an enzyme that can release potent vasoactive peptides and activate growth factors is of obvious interest and potential importance. We have examined rat vascular smooth muscle (VSM) cells in culture for the presence of the kallikrein-kinin system. We report that not only GKLE, but also kininogen and kininase(s) are synthesized by VSM cells. This raises the possibility that the kallikrein system may function as an autocoid mechanism in blood vessels. Moreover, the expression of these components in cell culture should facilitate studies of the regulation of synthesis of these key elements of the kallikrein system.

\begin{abstract}
Methods
${ }^{125} \mathrm{I}$-Tyr ${ }^{8}$-bradykinin and sodium ${ }^{125} \mathrm{I}$ (New England Nuclear, Boston, MA), Tosyl phenylalanine chloromethyl ketone (TPCK) treated trypsin and soybean trypsin inhibitor (Sigma Chemical Co., St. Louis), and platelet derived growth factor (PDGF), (New England Biolabs, Inc., Cambridge, MA) were obtained from commercial sources as indicated. An established rat vascular smooth muscle cell line, A7R513, was obtained from the American Type Culture Collection (Rockville, MD). Aprotinin (Trasylol) was a generous gift from Dr. P. Huber and Dr. G. L. Haberland of Bayer A. G., Wuppertal, West Germany.
\end{abstract}

\section{Preparation of rat aorta homogenate}

Male Sprague-Dawley rats were anesthetized with pentobarbital and injected with $0.1 \mathrm{ml}$ heparin $(5,000 \mathrm{U} / \mathrm{ml})$ into the vena cava. The heart was cut and used to lift aorta. The aorta was cut and placed in a petri dish containing saline. The tissue was rinsed with several changes of saline until free of any visible blood. The aorta was stripped of adventitia, blotted dry on a filter paper and cut into $1-\mathrm{cm}$ rings. If endothelium was to be removed, a forcep was inserted into the aortic rings and the tissue was rolled over a filter paper about three to five

1. Abbreviations used in this paper: GKLE, glandular kallikrein-like enzyme; PDGF, platelet-derived growth factor; SBTI, soybean trypsin inhibitor; TPCK, tosyl phenylalanine chloromethyl ketone; VSM, vascular smooth muscle. 
times. Aortic rings with or without endothelium were weighed, placed in a centrifuge tube, and $0.1 \mathrm{M}$ sodium phosphate buffer, $\mathrm{pH} 7.4$, containing $0.5 \%$ Triton was added. The tissue was frozen and thawed four times and then homogenized intermittently for $5 \mathrm{~min}$ on ice. The homogenate was centrifuged at $30,000 \mathrm{rpm}$ for $30 \mathrm{~min}$. The supernatant was dialyzed against the phosphate buffer, $\mathrm{pH} 7.4$, for $18 \mathrm{~h}$ at $4^{\circ} \mathrm{C}$. The dialyzed sample was used for the analysis of kallikrein.

\section{Preparation and culture of rat VSM}

Rat aortic smooth muscle cells for primary culture were isolated by enzymatic dispersion by a method adapted from Gunther et al. (13). These cells and cells from the A7R513 line were cultured by standard methods. The medium was Dulbecco's modified Eagle's medium (DME) containing $20 \%$ fetal calf serum. The medium was changed every $3 \mathrm{~d}$ and confluent monolayers were obtained within $15 \mathrm{~d}$. Cells of passages 2-15 were used in these studies. Culture flasks provided a surface area of $75 \mathrm{~cm}^{2}$ and contained $\sim 5 \times 10^{6}$ cells at confluence. Typically, confluence occurred after $4 \mathrm{~d}$ with the A7R513 line and after $6 \mathrm{~d}$ of growth with the primary cultures. Once cells achieved confluence they were incubated in $12 \mathrm{ml}$ DME containing only $0.1 \%$ fetal calf serum for at least $48 \mathrm{~h}$ before determination of kallikrein or other components. For certain studies cultures were also grown from passage to confluence in $\mathrm{K} 1$ serum-free defined media (14) supplemented with $0.5 \mathrm{U} / \mathrm{ml}$ PDGF. The cells were identified as VSM cells by the presence of $\alpha 1$-actin, the specific isoform found in VSM cells by immunohistochemistry.

\section{Preparation of VSM and media for assay}

Cell homogenate. After the aspiration of medium, cultured cells were collected by scraping the cells off the surface of the culture flask with a spatula and resuspending them in $1 \mathrm{ml}$ of RIA buffer $(0.05 \mathrm{M}$ Tris$\mathrm{HCl}, \mathrm{pH} 7.4,0.1 \%$ gelatin) and the cell suspension was sonicated. Each batch consisted of the cells pooled from two to three, $75-\mathrm{cm}^{2}$ flasks. Each flask yielded $0.5-1.5 \mathrm{mg}$ protein. The sonicated cell homogenate was centrifuged at $10,000 \mathrm{rpm}$ for $20 \mathrm{~min}$, and the pellet was discarded. (In pilot experiments the pellet was reextracted in $0.1 \%$ Triton and found to contain no kallikrein). The supernatant was stored at $-70^{\circ} \mathrm{C}$ until analyzed.

Media. Media were collected by aspiration, centrifuged at 2,000 $\mathrm{rpm}$ for $\mathbf{2 0} \mathrm{min}$, and stored frozen. (In some experiments the media were dialyzed against $0.05 \mathrm{M}$ Tris- $\mathrm{HCl}$ buffer $\mathrm{pH} 7.4$ for $18 \mathrm{~h}$ at $4^{\circ} \mathrm{C}$ to exclude smaller molecules that may interfere with assays. No differences between dialyzed and nondialyzed media were detected.)

\section{Direct RIA of kallikrein}

Kallikrein was determined using our direct RIA (15). Standard curves were developed using ${ }^{125}$ I-kallikrein and rabbit anti-rat urinary kallikrein antibody. Our antibody is extensively characterized (16) and is known to recognize active as well as inactive kallikrein (total kallikrein).

\section{Kininogenase assay}

Kininogenase activity was determined using our microkininogenase assay (17). Briefly, tissue homogenates or media were incubated with partially purified dog kininogen for $24 \mathrm{~h}$. The liberated kinins were purified by ethanol extraction and assayed by kinin RIA.

\section{Kinin-RIA}

Our kinin RIA has been published (18). Briefly, we use ${ }^{125} \mathrm{I}$ $\mathrm{Tyr}^{8}$-bradykinin as an antigen and highly sensitive antibradykinin serum to develop the standard curve. The least detectable amount of kinin in this RIA is $1 \mathrm{pg} /$ tube.

\section{Kininogen determination}

The tissue homogenates or media were incubated with TPCK-trypsin $(16,19)$. The reaction was terminated by placing the tubes in a boiling water bath and the generated kinins were isolated and estimated by the kinin-RIA.

\section{Kininase assay}

We used ${ }^{125} \mathrm{I}-\mathrm{Tyr}^{8}$-bradykinin as a substrate and the loss in immunoreactivity of this radiolabelled bradykinin with kinin antibody as the index of kinin degradation.

\section{Protein determination}

Protein microassay (Bio-Rad Chemical Division, Richmond, CA) was used according to the directions of the manufacturer to estimate proteins.

\section{Results}

Rat aorta. Blood-free rat aorta homogenate contained 15.4 \pm 3.2 (SD) ng GKLE/mg protein $(n=3)$. Aorta denuded of endothelium contained $15.2 \pm 4.2 \mathrm{ng} / \mathrm{mg}(n=3)$. Immunologically, GKLE was similar to rat urinary kallikrein as demonstrated by displacements of ${ }^{125}$ I-kallikrein-antikallikrein conjugate (Fig. 1).

In one trial, a homogenate of rat aorta demonstrated kininogenase activity, generating $0.573 \mathrm{ng} \mathrm{kinin} / \mathrm{mg}$ tissue protein $/ \mathrm{h}$ from added kininogen. Nolly et al. (12) reported similar activity, $0.605 \mathrm{ng} / \mathrm{mg} / \mathrm{h}$.

VSM cells in culture. Two preparations of rat VSM cells were studied, a primary culture and an established cell line (A7R513 from the American Type Culture collection). Media in which the cells were grown during the final $24 \mathrm{~h}$ also were tested for components of kallikrein-kinin system. Results are given in Table $\mathrm{I}$.

GKLE. Both types of VSM cells contained GKLE easily detectable by a direct radioimmunoassay. There was a tendency toward higher concentration of GKLE in VSM cells from the cell line than in primary culture cells, but this difference was not statistically significant (by $t$ test for unpaired values). GKLE was also determined in primary cultures grown entirely in defined media to eliminate any possibility that GKLE was a contaminant from the fetal calf serum present in the standard culture media. GKLE was detected in all three batches grown in defined media. The mean content was higher

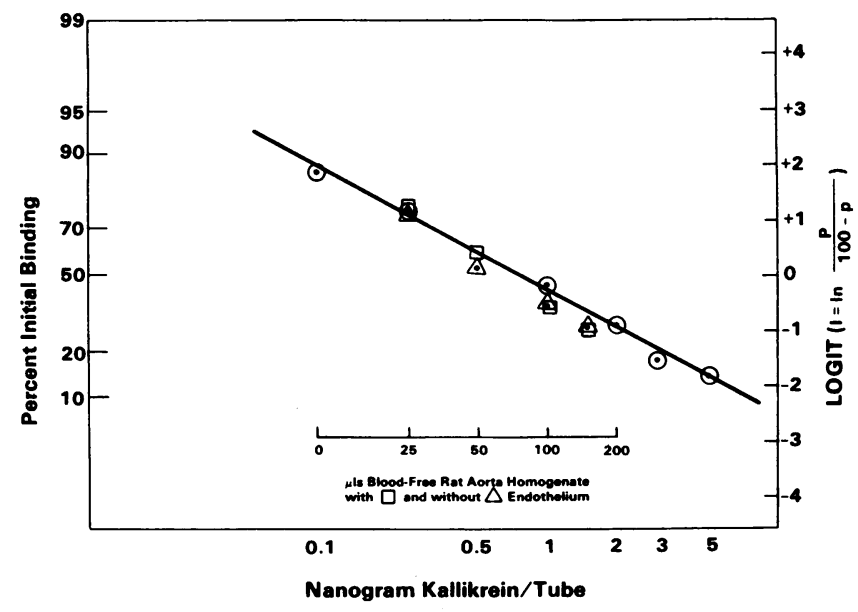

Figure 1. A standard curve (-O - of a direct RIA of rat urinary kallikrein is compared with the displacements obtained by different aliquots of homogenates of aorta with $(-\square-)$ and without $(-\Delta-)$ endothelium. The displacements obtained with aortic homogenates were indistinguishable from that of pure rat urinary kallikrein. 
Table I. Kallikrein System Components in Cultured VSM Cells

\begin{tabular}{llcr}
\hline & Primary culture & Cell line & Media \\
\hline GKLE $^{\ddagger}$ & & & \\
$\begin{array}{c}\text { Cells grown in } \\
\text { regular medium }\end{array}$ & $4.8 \pm 0.74(3)^{*}$ & $9.5 \pm 2.4(4)$ & $4.9 \pm 2.2(3)$ \\
$\begin{array}{c}\text { Cells grown in } \\
\quad \text { defined medium }\end{array}$ & $15.1 \pm 10.0(3)$ & - & $5.0 \pm 1.2(4)$ \\
Kininogen $^{\ddagger}$ & $30.5 \pm 8.0(4)$ & $26.5(1)$ & $27.4 \pm 3.8(3)$
\end{tabular}

* Values are mean $\pm \mathrm{SD}$. Number of batches tested in parentheses.

${ }^{\ddagger}$ Units are $\mathrm{ng} / \mathrm{mg}$ protein for cell homogenates, $\mathrm{ng} / \mathrm{ml}$ for media.

than that in VSM cells grown in regular media. However, the difference was not significant because variation in the definedmedia samples was increased greatly by one very high value $(8.1,10.3,27.0)$. These values all exceed those from VSM cells grown in regular media $(4.5,5.6,4.2)$. Media from both primary and cell line VSM cells contained GKLE by RIA. Displacements by VSM cell homogenates in the RIA were parallel to the standard curve obtained with rat urinary kallikrein (Fig. 2), suggesting immunological homology between GKLE in VSM and urinary kallikrein. GKLE in culture media also demonstrated parallelism with standards in the RIA (data not shown).

Qualitatively, homogenates of cells grown in primary culture invariably generated kinins upon incubation with dog kininogen suggesting the occurrence of kininogenase activity in VSM cells. Since quantitation and a complete assessment of the nature of kininogenase activity require a large amount of sample, the full analysis was performed in two representative batches; one grown in defined media and the other in regular $\mathrm{K} 1 \mathrm{media}$. The homogenate of the VSM cells grown in defined media generated $32.5 \mathrm{ng}$ kinins $/ \mathrm{mg}$ protein $/ 24 \mathrm{~h}$. After treatment of the homogenate with trypsin to activate inactive kallikrein, $58.8 \mathrm{ng} / \mathrm{mg}$ per $24 \mathrm{~h}$ were generated. Thus, $\sim 55 \%$ of GKLE appeared to be in active and $45 \%$ in an inactive form. This kininogenase activity (active form) was entirely inhibited by addition of $10 \mu \mathrm{g}$ aprotinin during incubation. No kinins above reagent blanks could be detected. Addition of SBTI decreased kinin generation by $\sim 20 \%$ to $26.3 \mathrm{ng} / \mathrm{mg}$ per $24 \mathrm{~h}$. Comparable results were obtained with homogenate from the other batch of VSM grown in the regular K1 media: $61 \%$ of GKLE was active and this activity was inhibited $100 \%$ by aprotinin and $25 \%$ by SBTI.

Kininogen. Kininogen was detected in all VSM cultures. In four primary cultures, $610 \pm 160 \mathrm{pg}$ of kinins were generated per mg of cell protein after complete digestion with excess TPCK-trypsin. Values in Table I have been converted to nanograms of kininogen by multiplying kinins by 50 , with the assumption that kinins comprise $2 \%$ of VSM kininogen, as is true of urinary kininogen $(15,18)$. A batch of primary culture VSM grown in defined media contained $21.5 \mathrm{ng} / \mathrm{mg}$ kininogen. Kininogen was also detected in three media from primary cultures (Table I); two were regular media, one was a defined medium.

Bradykininase(s). As shown in Fig. 3, ${ }^{125} \mathrm{I}$-bradykinin was rapidly degraded when it was incubated with intact VSM cells in primary culture. Bradykinin was not degraded by prolonged incubation with medium alone (control, Fig. 3). Similar observations were made in five additional experiments with VSM cell homogenates and four with media in which VSM cells had been grown. In each case, bradykinin was rapidly degraded. Bradykininase activity also was readily detected in a batch of VSM cells grown in defined media.

\section{Discussion}

Nolly et al. (12) found that rat arteries and veins contain a GKLE that resembles urinary kallikrein in terms of immunogenicity and certain inhibitory characteristics. We have confirmed this observation and now report that GKLE is present in VSM cells cultured from rat aorta. This indicates that GKLE can be synthesized by vascular tissue and is not merely deposited from glandular kallikrein known to be present in the blood (15). The present data suggest that VSM is the locus of GKLE synthesis. Two observations indicate that the enzyme is of the glandular type. Displacements by VSM homogenates in the RIA are parallel to those obtained with urinary kallikrein (Fig. 2). Moreover, kininogenase activity of VSM homoge-

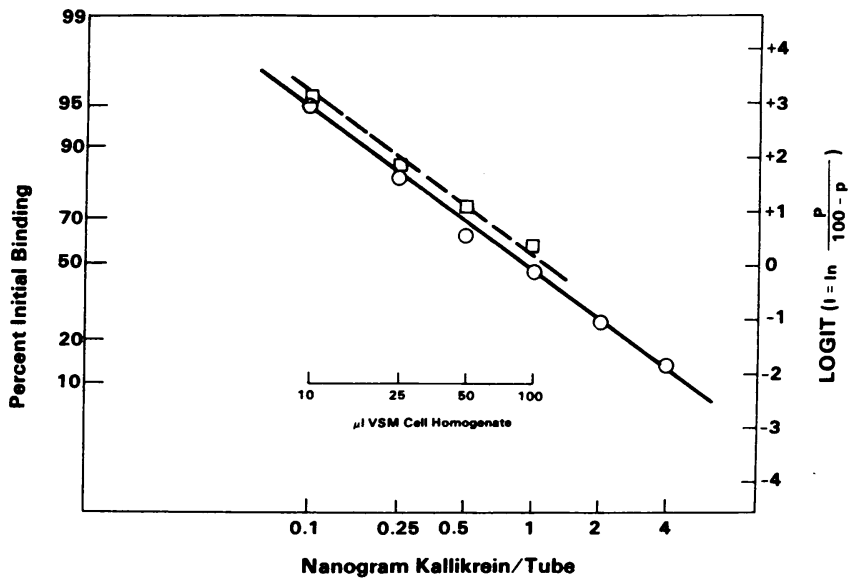

Figure 2. A standard curve (mean of three assays) (-O - ) is compared with the mean of three determinations $(-\square-)$ of VSM cell homogenate.

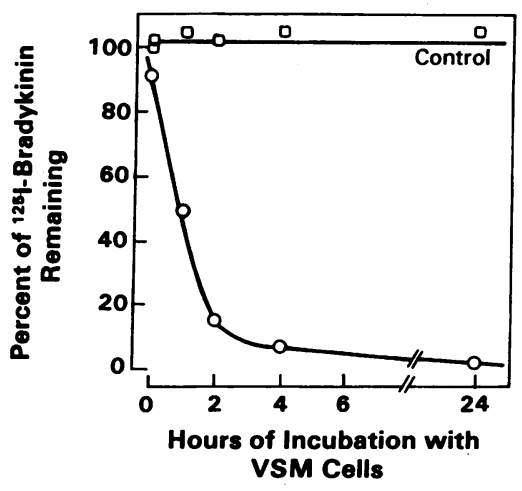

Figure 3. Radiolabeled bradykinin, 1.6 million $\mathrm{cpm}$ in $10 \mathrm{ml}$ growth media, was added in one flask without cells (- $\square-$ control) and in the other flask containing the primary culture of the VSM cells - $\mathrm{O}-$, and incubated for $24 \mathrm{~h}$. At specified time intervals triplicate aliquots of $25 \mu \mathrm{l}$ $(\sim 4,000 \mathrm{cpm})$ were taken up into $10 \mu \mathrm{l}$ of 1 $\mu \mathrm{m}$ Captopril in buffer and stored at $4^{\circ} \mathrm{C}$. At the end of the experiment all the tubes were reacted with kinin antibody and the percent binding was compared with the binding of untreated tracer directly reacted with the kinin antibody. Loss in immunoreactivity of ${ }^{125} \mathrm{I}$ bradykinin was regarded as an index of degradation. 
nates is completely inhibited by aprotinin but is inhibited only $20 \%$ by SBTI. Our data suggest that about one-half of GKLE in VSM is in an inactive form that can be activated by trypsin. This is consistent with glandular kallikrein in rat urine (16). Since aorta denuded of endothelium had the same amount of GKLE as intact aorta in our study and Hial et al. (20) did not find kallikrein in human endothelial cells in culture, it is likely that VSM cells are the principal and possibly the only type of vascular cells that make kallikrein.

We detected GKLE both in primary cultures and in an established VSM cell line. GKLE was also readily detected in VSM cells grown in a defined medium. This eliminates the possibility that the GKLE detected in VSM cells grown in regular media, which contain fetal calf serum, is a contaminant from the calf serum. Indeed, the content of GKLE tended to be higher in VSM cells grown in defined than in regular media. We speculate that growth factors added to the defined media (PDGF, insulin, and cortisol) may stimulate synthesis of GKLE.

We also have found that VSM cells in culture synthesize kininogen and bradykininase(s) activity. All three components are secreted into culture media. Thus, all the key components of the kallikrein system are present in arterial tissue, where they may function as an autocrine system. Kinins liberated locally may help regulate vascular tone. Kallikrein itself processes growth factors, hormones and other proteins and thereby may help modulate growth and function of VSM cells or nearby endothelial cells. If the kallikrein system components are released into the blood in vivo as they are into the medium in cell cultures, they may affect resistance vessels downstream. The tone of resistance vessels also may be modulated locally by the kallikrein system, if smooth muscle cells of resistance vessels themselves synthesize the key components.

\section{Acknowledgments}

Technical assistance of Ms. Catherine Murphy and secretarial assistance of Ms. Susan Freeley is very much appreciated.

This work was supported by grants HL-31417 and HL-18318 from the National Institutes of Health.

\section{References}

1. Ashley, P. L., and R. J. MacDonald. 1985. Tissue-specific expression of kallikrein-related genes in the rat. Biochemistry. 24:4520 4527.

2. MacDonald, R. J., H. S. Margolius, and E. G. Erdos. 1988. Molecular biology of tissue kallikrein. Biochem. J. 253:313-321.

3. Sealey, J. E., S. T. Atlas, J. H. Laragh, N. B. Oza, and J. W. Ryan. 1978. Human urinary kallikrein converts inactive to active renin and is a possible physiological activator of renin. Nature (Lond.). 275:144145.

4. Ole-Moi Yoi, O., D. C. Saldin, J. Spragg, G. S. Pinkus, and K. F. Austen. 1979. Sequential cleavage of proinsulin by human pancreatic kallikrein and a human pancreatic kininase. Proc. Natl. Acad. Sci. USA. 76:3612-3616.

5. Bothwell, M. A., W. H. Wilson, and E. M. Shooter. 1979. The relationship between glandular kallikrein and growth factor-processing proteases of mouse submaxillary gland. J. Biol. Chem. 254:7287-7294.

6. Currie, M. G., D. M. Geller, J. Chao, H. S. Margolius, and P. Needleman. 1984. Kallikrein activation of a high molecular weight atrial peptide. Biochem. Biophys. Res. Commun. 120:461-466.

7. Cardin, A. D., K. R. Witt, J. Chao, H. S. Margolius, V. H. Donaldson, and R. L. Jackson. 1984. Degradation of apolipoprotein B-100 of human plasma low density lipoproteins by tissue and plasma kallikreins. J. Biol. Chem. 259:8522-8528.

8. Lewis, S. A., and W. P. Alles. 1986. Urinary kallikrein: A physiological regulator of epithelial $\mathrm{Na}^{+}$absorption. Proc. Natl. Acad. Sci. USA. 83:5345-5348.

9. Shimojo, N., J. Chao, L. Chao, H. S. Margolius, and R. K. Mayfield. 1987. Identification and characterization of a tissue kallikrein in rat skeletal muscles. Biochem. J. 243:773-778.

10. Chao, J., L. Chao, and H. S. Margolius. 1984. Identification of a kallikrein-like latent serine protease in human erythrocyte membranes. Biochem. Biophys. Res. Commun. 121:722-729.

11. Chao, J., C. Woodley, L. Chao, and H. S. Margolius. 1983. Identification of tissue kallikrein in brain and in the cell-free translation product encoded by brain mRNA. J. Biol. Chem. 258:1517315178.

12. Nolly, H., A. G. Scicli, G. Scicli, and O. A. Carretero. 1985. Characterization of a kininogenase from rat vascular tissue resembling tissue kallikrein. Circ. Res. 56:816-821.

13. Gunther, S., R. W. Alexander, W. J. Atkinson, and M. A Gimbrone. 1982. Functional Angiotensin II receptors in cultured vascular smooth muscle cells. J. Cell Biol. 92:289-298.

14. Selvaggio, A. M., J. H. Schwartz, H. H. Bengele, F. D. Gordon, and E. A. Alexander. 1988. Mechanism of $\mathrm{H}+$ secretion by inner medulary collecting duct cells. Am. J. Physiol. 254:F391-F400.

15. Oza, N. B. 1981. Development of a rat urinary kallikrein-binding radioimmunoassay and identification of homologus enzyme in plasma. J. Clin. Chem. Clin. Biochem. 19:1033-1038.

16. Weinberg, M. S., N. B. Oza, and N. G. Levinsky. 1984. Components of the kallikrein-kinin system in rat urine. Biochem. Pharmacol. 33:1779-1782.

17. Beasley, D., N. B. Oza, and N. G. Levinsky. 1987. Micropuncture localization of kallikrein secretion in the rat nephron. Kidney Int. 32:26-30.

18. Lieberthal, W., N. B. Oza, D. B. Bernard, and N. G. Levinsky. 1982. The effect of cations on the activity of human urinary kallikrein. J. Biol. Chem. 257:10827-10830.

19. Oza, N. B. 1988. A new direct radioimmunoassay of rat urinary kininogen. Biochem. Pharmacol. 37:1965-1969.

20. Hial, V., M. A. Gimbrone, M. P. Peyton, G. M. Wilcox, and J. J. Pisano. 1979. Angiotensin metabolism by cultured human vascular endothelial and smooth muscle cells. Microvasc. Res. 17:314-329. 